\title{
Toksoplasmosis Okular
}

\author{
Dessy Ariyeni ${ }^{1}$, Weni Helvinda ${ }^{2}$
}

Abstrak

Toksoplasmosis merupakan penyakit yang disebabkan oleh Toksoplasma gondii yang merupakan protozoa obligat intraselular. Parasit ini mempunyai tiga bentuk morfologi yang berbeda, yaitu: tachizoites, bradizoites dan ookista. Transmisi parasit ke manusia dapat terjadi dengan cara termakan makanan yang mengandung ookista atau kista jaringan yang terdapat di dalam daging yang dimasak tidak sempurna. Dilaporkan kasus dengan diagnosis toksoplasmosis okular pada lima pasien yang datang ke RSUP Dr. M. Djamil Padang antara Februari sampai Mei 2015. Lima pasien datang dengan keluhan penglihatan kabur dengan onset yang berbeda-beda. Pada pemeriksaan oftalmologi didapatkan penurunan visus unilateral dan terdapatnya lesi di polus posterior dengan pinggir hiperpigmentasi pada pemeriksaan funduskopi. Semua pasien diberikan terapi trimethoprim/sulfamethoxazole selama 6 minggu. Perbaikan visus pada pasien toksoplasmosis okular terjadi setelah pemberian terapi selama 6 minggu dengan terapi trimethoprim/sulfamethoxazole walaupun tidak terlalu signifikan karena ada lesi didaerah makula.

Kata kunci: lesi hiperpigmentasi, toksoplasmosis okular, trimethoprim / sulfamethoxazole

\section{Abstract}

Toxoplasmosis is a disease caused by Toxoplasma gondii which is an intracellular obligate protozoa. This parasite has three differents morphological forms: tachizoites, bradizoites and oocysts. Transmission of parasites to body can occur by eating food containing oocysts or tissue cysts contained in imperfectly cooked meat. It was been reported cases with the diagnosis of ocular toxoplasmosis in five patients who came to Dr. M. Djamil Padang between February - May 2015. Five patients presented with complaints of blurred vision with different onset. The ophthalmology examination revealed a unilateral decrease visual acuity and the presence of lesions in the posterior pole with hyperpigmented margins on fundoscopic examination. All patients were given trimethoprim/sulfamethoxazole therapy for six weeks. Improvement of visual acuity in patients with ocular toxoplasmosis occurred after six weeks of therapy with trimethoprim/sulfamethoxazole therapy, although not very significant because of the presence of lesions in the macular area.

Keywords: hyperpigmented lesions, ocular toxoplasmosis, trimethoprim / sulfamethoxazole

Affiliasi penulis: ${ }^{1}$ Dinas Kesehatan Kota Batam, Prov Kepulauan Riau. ${ }^{2 B a g i a n}$ IImu Kesehatan Mata, Fakultas Kedokteran, Universitas Andalas, Padang.

Korespondensi: dr.dessy.ariyeni@gmail.com, Telp: 082385850881

\section{PENDAHULUAN}

Toksoplasmosis adalah penyakit yang paling banyak menyebabkan retinochoroiditis infeksius baik pada dewasa maupun anak-anak. ${ }^{1}$ Penyakit ini disebabkan oleh parasit protozoa obligat intraselular. Toxoplasma gondii, dimana kucing merupakan host definitive. Toksoplasmosis pada manusia dapat terjadi dalam empat bentuk, yaitu; toksoplasmosis kongenital, toksoplasmosis didapat, toksoplasmosis pada pasien imunocompromised dan toksoplasmosis okular. ${ }^{2}$

Terdapat tiga bentuk Toxoplasma gondii, yaitu: tachizoites (tropozoites) yang merupakan bentuk invasif dan bertanggung jawab pada manifestasi infeksi akut, bradizoites yang merupakan bentuk parasit yang terdapat didalam kista jaringan, sporozoites (ookista) yang merupakan bentuk parasit yang terdapat di dalam kotoran kucing. ${ }^{3}$ Manusia dapat terinfeksi Toxoplasma gondii bila memakan 
daging yang terinfeksi kista jaringan yang dimasak tidak sempurna, memakan buah atau sayur yang terkontaminasi ookista dan transmisi secara transplasental dari ibu ke janin. ${ }^{4}$

Toksoplasmosis okular merupakan penyebab utama uveitis posterior di berbagai negara. Diperkirakan 25-30\% populasi terinfeksi Toxoplasma gondii. ${ }^{5}$ Keadaaan ini merupakan penyebab uveitis posterior pada $85 \%$ kasus di Brazil dan $25 \%$ kasus di Amerika. Seroprevalensi berbeda di berbagai negara, seperti seroprevalensi rendah dilaporkan pada Asia Tenggara, Amerika Utara dan Eropa Utara (10-30\%) dan seroprevalensi $30-50 \%$ pernah dilaporkan di Eropa Tengah dan Eropa Selatan. ${ }^{6}$

Penegakan diagnosis toksoplasmosis okular sebagian besar menunjukkan karakteristik gambaran retinitis necrotizing fokal yang terlihat lesi keputihan dengan batas kabur dengan dikelilingi edema retina. Gambaran ini bersamaan dengan vitritis dan uveitis anterior granulomatous. Selain itu juga dapat dilakukan pemeriksaan serologi antibodi toksoplasma untuk mendukung diagnosis toksoplasmosis okular. ${ }^{7}$

\section{KASUS}

1. Seorang pasien laki-laki, usia 35 tahun, datang pada tanggal 3 Maret 2015 dengan keluhan utama penglihatan mata kanan kabur sejak 2 minggu yang lalu. Sebelumnya penglihatan mata kanan kabur sejak 5 tahun yang lalu dan kabur yang dirasakan perlahan sejak 2 minggu yang lalu penglihatan mata kanan yang kabur sudah sangat mengganggu aktivitas. Keluhan penglihatan terhalang seperti tirai disangkal pasien. Riwayat kacamata tidak ada, mata merah berulang tidak ada, nyeri saat mata digerakkan tidak ada. Riwayat memelihara binatang peliharaan tidak ada. Pekerjaan pasien adalah seorang montir motor di bengkel.

2. Seorang pasien laki-laki, usia 72 tahun, datang pada tanggal 20 Maret 2015 dengan keluhan utama penglihatan mata kanan kabur sejak 5 bulan yang lalu dirasakan perlahan dan semakin kabur sejak 2 bulan yang lalu seperti melihat kabut. Riwayat mata merah, nyeri saat mata digerakkan, riwayat trauma tidak ada, memelihara binatang peliharaan tidak ada. Riwayat kacamata tidak ada. Riwayat DM sejak 4 tahun yang lalu dan terkontrol.
3. Seorang pasien laki-laki, usia 22 tahun, datang pada tanggal 7 April 2015 dengan keluhan utama penglihatan mata kanan kabur sejak 2 minggu yang lalu. Riwayat mata merah, nyeri saat mata digerakkan dan riwayat kacamata tidak ada. Pasien mempunyai riwayat memelihara binatang peliharaan.

4. Seorang pasien anak perempuan, usia 12 tahun, datang pada tanggal 9 April 2015 dengan keluhan utama penglihatan mata kanan kabur dan baru disadari saat pemeriksaan mata di sekolah. Riwayat mata merah, nyeri saat mata digerakkan, riwayat trauma dan riwayat kaca mata tidak ada. Riwayat memelihara binatang peliharaan tidak ada.

5. Seorang pasien anak laki-laki, usia 9 tahun datang pada tanggal 6 April 2015 dengan keluhan utama penglihatan mata kiri terasa kabur sejak 3 bulan yang lalu. Kabur dirasakan perlahan. Riwayat mata merah, nyeri saat mata digerakkan, riwayat trauma, riwayat kacamata dan memelihara binatang tidak ada.

\section{Hasil Pemeriksaan}

1. Pemeriksaan oftalmologi pada pasien pertama didapatkan visus mata kanan 1/60 dan mata kiri 5/6. Pemeriksaan funduskopi mata kanan tampak dua lesi dengan batas tidak tegas dan reflek fovea tidak ada. Pemeriksaan penunjang imunoserologi anti toksoplasma $\lg \mathrm{G}=259 \mathrm{IU} / \mathrm{ml}$.

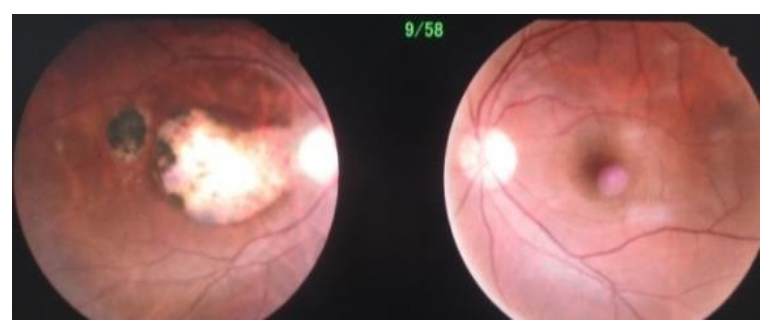

Gambar 1. Lesi hiperpigmentasi OD

Pasien ini didiagnosis dengan Chorioretinitis e.c Toksoplasma OD. Terapi yang diberikan adalah Bactrim $F$ 2x960 mg, prednison 1×60 mg, ranitidin 2x150 mg. Pasien ini mendapatkan terapi yang sama selama 10 minggu. Visus mata kanan mengalami sedikit perubahan namun tidak terlalu signifikan karena lesi didaerah makula. Terjadi penurunan kadar antitoksoplasma $\mathrm{lgG}=185 \mathrm{IU} / \mathrm{ml}$ pada minggu keempat. 
2. Pemeriksaan oftalmologi yang didapatkan pada pasien kedua visus mata kanan 1/60 dan mata kiri 5/60. Pemeriksaan funduskopi mata kanan tampak lesi batas kabur dan reflek fovea tidak ada. Pemeriksaan penunjang imunoserologi anti toksoplasma $\lg G=323$ $\mathrm{IU} / \mathrm{ml}$.

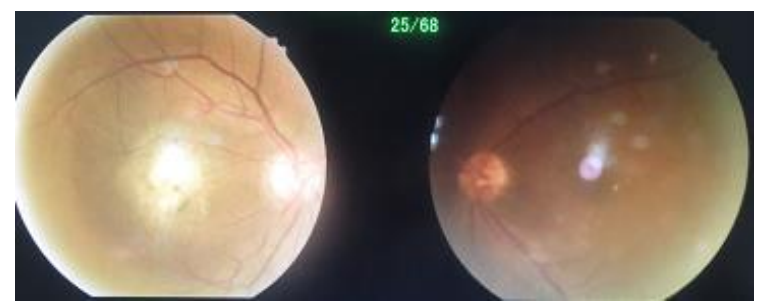

Gambar 2. Lesi aktif OD

Pasien didiagnosis dengan Chorioretinitis ec Toksoplasma OD, Moderate NPDR + CSME OS. terapi yang diberikan bactrim F 2x960 mg, prednison $1 \times 65 \mathrm{mg}$ dan ranitidin $2 \times 150 \mathrm{mg}$. Pasien ini mendapatkan terapi yang sama selama 6 minggu. Visus mata kanan mengalami sedikit perubahan pada akhir pengobatan karena lesi di daerah makula dan terdapatnya retinopati diabetikum. Terjadi penurunan kadar antitoksoplasma lgG $=58 \mathrm{IU} / \mathrm{ml}$ pada minggu keempat.

3. Pemeriksaan oftalmologi pada pasien ketiga didapatkan penurunan visus mata kanan menjadi 5/7 dan mata kiri 5/5. Pemeriksaan funduskopi mata kanan tampak lesi batas kabur, reflek fovea (+).

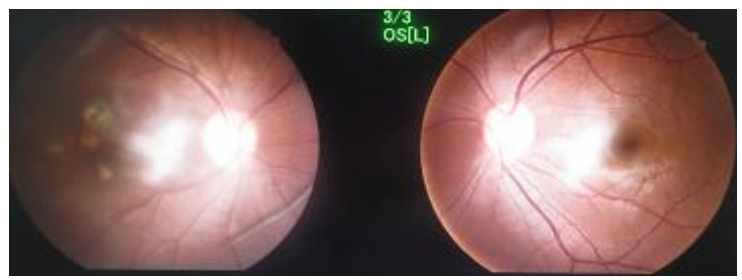

Gambar 3. Lesi hiperpigmentasi OD

Pasien didiagnosis dengan Chorioretinitis ec susp Toksoplasma OD dan direncanakan untuk dilakukan pemeriksaan serologi IgG, IgM anti toksoplasma. Namun pasien tidak datang kembali untuk kontrol.

4. Pemeriksaan oftalmologi pasien keempat didapatkan visus mata kanan $21 \frac{1}{2} / 60$ dan mata kiri
5/7. Pemeriksaan funduskopi didapatkan lesi batas kabur, hiperpigmentasi (+), reflek fovea (+). Pemeriksaan imunoserologi lgG anti toksoplasma: 99 IU/L.

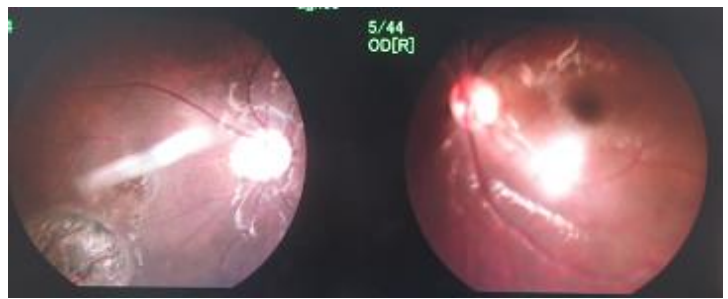

Gambar 4. Lesi hiperpigmentasi OD

Pasien didiagnosis dengan chorioretinitis ec Toksoplasma ODS. Terapi yang diberikan bactrim 2x480 mg, prednison $1 \times 40 \mathrm{mg}$, ranitidin 2x150 mg. Pasien tidak datang untuk control berikutnya.

5. Pemeriksaan oftalmologi pasien kelima didapatkan visus mata kanan 5/5 dan mata kiri 5/15. Pemeriksaan funduskopi ditemukan lesi (+), batas kabur, hiperpigmentasi $(+)$, reflek fovea (-). Pemeriksaan imunoserologi anti Toksoplasma IgG 113 IU/L.

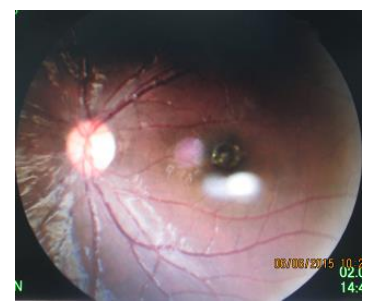

Gambar 5. Lesi hiperpigmentasi di daerah makula OS

Pasien didiagnosis dengan chorioretinitis ec Toksoplasma OS dan mendapat terapi bactrim 2x480 mg, prednison $1 \times 45 \mathrm{mg}$, ranitidine $2 \times 150 \mathrm{mg}$. Pasien ini juga tidak datang untuk control berikutnya.

\section{PEMBAHASAN}

Toksoplasmosis merupakan penyakit yang disebabkan oleh Toksoplasma gondii yang merupakan protozoa obligat intraselular. Parasit ini mempunyai tiga bentuk morfologi yang berbeda, yaitu: tachizoites merupakan bentuk aseksual yang dapat menyebabkan kerusakan jaringan host dimana dalam bentuk kista terdiri dari bradizoites yang merupakan stadium 
dormant parasit dalam jaringan, sedangkan ookista merupakan bentuk seksual parasit yang terdapat pada usus kucing dan dikeluarkan dalam bentuk sporozoites. ${ }^{7}$ Transmisi parasit ke manusia dapat terjadi dengan cara termakan makanan yang mengandung ookista atau kista jaringan yang terdapat di dalam daging yang dimasak tidak sempurna. ${ }^{8}$

Dilaporkan kasus dengan diagnosis toksoplasmosis okular pada 5 pasien yang datang ke RS Dr. M. Djamil Padang antara bulan Februari - Mei 2015. Kelima pasien datang dengan keluhan pandangan kabur dengan onset yang berbeda-beda.

Pasien pertama datang dengan keluhan pandangan mata kanan kabur sejak 5 tahun yang lalu secara perlahan-lahan dan keluhan dirasakan semakin mengganggu aktifitas sejak 2 minggu sebelum ke rumah sakit. Riwayat memelihara binatang peliharaan terutama kucing disangkal oleh pasien.

Pasien kedua datang dengan keluhan pandangan mata kanan kabur sejak 5 bulan yang lalu yang dirasakan perlahan dan semakin kabur sejak 2 bulan sebelum ke rumah sakit. Riwayat memelihara binatang peliharaan terutama kucing disangkal oleh pasien.

Pasien ketiga datang dengan keluhan mata kanan kabur sejak 2 minggu sebelum ke rumah sakit. Riwayat memelihara binatang peliharaan terutama kucing diakui oleh pasien.

Pasien keempat datang dengan keluhan mata kanan kabur sejak 5 bulan yang lalu. Pasien baru menyadari mata kanan kabur saat ada pemeriksaan mata di sekolah. Riwayat memelihara binatang peliharaan terutama kucing diakui oleh pasien.

Pasien kelima datang dengan keluhan mata kiri kabur sejak 3 bulan sebelum ke rumah sakit. Riwayat memelihara binatang peliharaan disagkal oleh pasien.

Anamnesis kelima pasien mengeluhkan pandangan kabur pada satu mata. Menurut teori, gejala pada 90\% pasien akan mengeluhkan pandangan kabur, menurunnya visus dan adanya floater karena adanya sel inflamasi yang dapat ditemukan pada vitreus yang berada di dekat lesi yang aktif. Hal ini merupakan gejala yang paling sering pada toksoplasmosis okular yang disebabkan oleh lesi aktif yang disertai oleh reaksi inflamasi pada vitreus yang akan terlihat gambaran klasik "headlight in the fog" yang menyebabkan pandangan kabur (gambar 1$){ }^{8}$

Pada laporan kasus ini, dari kelima pasien tidak ditemukan adanya kekeruhan vitreus yang menyebabkan pandangan kabur tetapi pandangan kabur diakibatkan oleh lesi yang berada di daerah makula. Pasien juga dapat mengeluhkan metamorphopsia akibat lesi retina yan berada dekat dengan makula. ${ }^{9}$

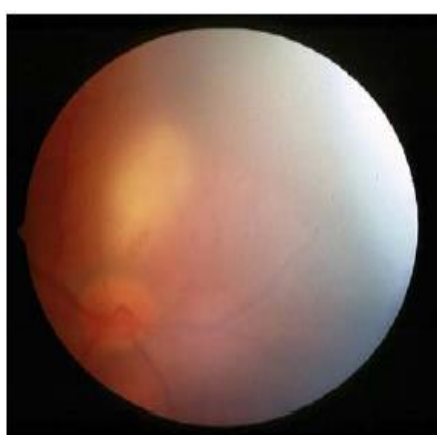

Gambar 6. Lesi aktif dengan reaksi inflamasi pada vitreus ("headlight in the fog") 8

Pemeriksaan fisik pada pasien pertama didapatkan visus mata kanan 1/60 ph (-) dan visus mata kiri $5 / 6$ ph 5/5. Pasien kedua didapatkan visus mata kanan 1/60 ph (-) dan visus mata kiri 5/60 ph $5 / 25$. Pasien ketiga didapatkan visus mata kanan $5 / 7$ ph (-) dan mata kiri 5/5. Pasien keempat didapatkan visus mata kanan 2 1/2 /60 cc S-3.00C-2.25 (180) $\rightarrow 5 / 6$ dan visus mata kiri $5 / 7$ cc C- $0.75(180) \rightarrow 5 / 5$. Pasien kelima didapatkan visus mata kanan $5 / 5$ dan visus mata kiri 5/15 f ph (-). Semua pasien didapatkan penurunan visus unilateral.

Penurunan visus pada toksoplasmosis okular terjadi karena beberapa alasan. Inflamasi vitreus yang banyak dapat secara signifikan menurunkan visus, juga karena lesi yang berada pada polus posterior dengan edema retina dan reaksi inflamasi yang berpengaruh pada visus. Lesi pada toksoplasmosis okular dapat terjadi didaerah manapun dari fundus. ${ }^{10}$ Toxoplasma mempunyai kecendrungan untuk jaringan saraf, sangat penting untuk memikirkan lesi berawal pada retina yang dapat menyebabkan inflamasi tidak hanya pada lapisan retina tetapi juga koroid. Lesi diluar daerah makula membedakan lesi toksoplasmosis yang terjadi pada pasien merupakan 
toksoplasmosis yang didapat atau toksoplasmosis kongenital, dimana biasanya pada toksoplasmosis kongenital lesi berada didaerah makula dan terdapat pada kedua mata. ${ }^{11}$

Pemeriksaan status oftalmologi segmen anterior pada kelima pasien didapatkan dalam batas normal atau tidak ditemukan adanya tanda-tanda infamasi. ${ }^{12}$ Pada toksoplasmosis okular dapat ditemukan reaksi inflamasi pada segmen anterior, seperti: injeksi siliar, Keratic Presipitat (KPs), reaksi pada bilik mata depan, seperti: sel dan flare (gambar 2). ${ }^{13}$

Pemeriksaan funduskopi pada pasien pertama didapatkan macula: tampak 2 lesi batas tidak tegas, hiperpigmentasi, reflek fovea (-).

Pada pasien kedua didapatkanmmakula: tampak lesi batas kabur, reflek fovea (-).

Pada pasien ketiga didapatkan makula: tampak lesi batas kabur, reflek fovea (+).

Pada pasien keempat didapatkan makula: tampak lesi batas kabur, hiperpigmentasi (+), reflek fovea $(+)$.

Pada pasien kelima didapatkan makula: tampak lesi (+), batas kabur, hiperpigmentasi (+), reflek fovea $(-)$.

Pada sebagian besar kasus retinochoroiditis toksoplasma merupakan self-limitted disease. Lesi yang tidak diterapi akan sembuh sendiri setelah 1 atau 2 bulan, walaupun pada beberapa kasus lesi dapat bertahan dalam beberapa bulan. Pada pasien imunokompeten, setelah beberapa bulan pada pinggir lesi akan menjadi hiperpigmentasi dengan bagian tengah yang atropik. ${ }^{14}$ Pada pasien imunosupresi, seperti pasien HIV atau pasien kanker lesi akan terlihat tunggal atau multifokal pada satu atau kedua mata dengan area retina nekrosis yang luas. Pada sebagian besar kasus tidak memiliki sikatrik dari lesi sebelumnya. ${ }^{15}$

Lesi pada retinochoroiditis toksoplasma mempunyai predileksi pada polus posterior terutama didaerah makula, berdasarkan perbandingan dari total area retina yang terkena, lesi makula lebih sering terjadi pada $76 \%$ pasien. Retinochoroiditis pada toksoplasmosis okular ditemukan sebagai retinitis yang melibatkan inner layer retina dengan gambaran lesi berwarna putih, yang dikelilingi retina yang edema.
Retina merupakan tempat infeksi primer tetapi sklera dan choroid dapat terlibat sekunder akibat respon inflamasi. ${ }^{16}$

Lesi aktif yang rekuren berada didekat sikatrik yang lama atau sikatrik inaktif yang disebut lesi satelit. Lesi juga dapat berada pada daerah yang jauh dari lesi primer. Secara kontras, pasien dengan toksoplasmosis okular yang didapat biasanya unilateral, soliter, dan lesi aktif tanpa adanya bukti sikatrik retinochoroidal sebelumnya. Berbeda dengan toksoplasmosis kongenital dimana lesi biasanya bilateral dan biasanya lesi aktif terdapat pada pinggir sikatrik retinochoroidal sebelumnya. Pada kasus dengan sumber infeksi dapat ditentukan, penyebab infeksi yang didapat lebih sering menyebabkan toksoplasmosis okular dibandingkan toksoplasmosis kongenital. ${ }^{17}$

Pemeriksaan serologi $\lg G$ dan $\lg M$ anti toksoplasma didapatkan hasil yang berbeda pada tiap pasien. Pada pasien pertama dan kedua dilakukan beberapa kali pemeriksaan serologi yang dilakukan sebelum mendapatkan terapi dan saat sedang mendapatkan terapi. Pada pasien ketiga tidak sempat dilakukan pemeriksaan serologi karena pasien tidak datang kembali untuk kontrol. Pada pasien keempat dan kelima hanya melakukan 1 kali pemeriksaan saat sebelum diberikan terapi dan pasien tidak datang kembali untuk melanjutkan terapi.

Hasil pemeriksaan serologi pasien pertama sebelum diberikan terapi, yaitu: anti Toksoplasma IgG = $259 \mathrm{IU} / \mathrm{ml}$ dan Anti Toksoplasma $\operatorname{lgM}=$ negatif. Dilakukan pemeriksaan serologi ulang pada minggu keempat setelah pasien mendapatkan terapi dengan hasil: anti Toksoplasma $\lg G=185 \mathrm{IU} / \mathrm{ml}$ dan Anti Toksoplasma $\operatorname{lgM}=$ negatif. Dilakukan pemeriksaan kembali pada minggu kedelapan dengan hasil: anti Toksoplasma IgG = $175 \mathrm{lU} / \mathrm{ml}$ dan Anti Toksoplasma $\lg \mathrm{M}=$ negatif.

Hasil pemeriksaan serologi pasien kedua sebelum diberikan terapi, yaitu: anti Toksoplasma IgG = $323 \mathrm{IU} / \mathrm{ml}$ dan Anti Toksoplasma $\operatorname{lgM}=$ negatif. Dilakukan pemeriksaan serologi ulang pada minggu keempat setelah pasien mendapatkan terapi dengan hasil: anti toksoplasma $58 \mathrm{IU} / \mathrm{L}$, IgM anti toksoplasma: negatif. 
Pada pasien ketiga tidak sempat dilakukan pemeriksaan serologi karena pasien tidak datang kontrol kembali.

Hasil pemeriksaan serologi pasien keempat sebelum diberikan terapi, yaitu: IgG anti toksoplasma: 99 IU/L dan IgM anti toksoplasma: negatif.

Hasil pemeriksaan serologi pasien kelima sebelum diberikan terapi, yaitu: IgG anti toksoplasma: 113 IU/L dan IgM anti toksoplasma: negatif.

Pada pasien keempat dan kelima tidak dapat dilakukan pemeriksaan serologi ulangan karena pasien tidak datang untuk kontrol kembali.

Pada laporan kasus ini terdapat keterbatasan karena dari 5 pasien yang dilaporkan hanya 2 pasien yang dapat dilakukan pemeriksaan serologi ulangan dan melanjutkan terapi hingga selesai karena pasien datang untuk kontrol dan mendapatkan terapi. Sedangkan 3 pasien lainnya tidak datang kembali untuk kontrol dengan berbagai alasan baik karena alasan biaya (untuk pemeriksaan serologi di laboratorium swasta) maupun kesediaan untuk kontrol berulang kali karena alasan jarak rumah yang jauh dari RSUP Dr. M. Djamil. Terdapat perbedaan yang sangat signifikan pada 2 pasien yang dilakukan pemeriksaan serologi ulangan. Pada pasien pertama terdapat penurunan pemeriksaan serologi anti toksoplasma IgG sebanyak 74 poin sedangkan pada pasien kedua terdapat penurunan pemeriksaan serologi anti toksoplasma IgG sebanyak 256 poin. Hal ini dikarenakan lesi pada pasien pertama cukup besar $>1$ disc diameter sehingga penurunan pemeriksaan serologi ulang tidak terjadi signifikan seperti pada pasien kedua.

Diagnosis toksoplasmosis okular ditegakkan berdasarkan pemeriksaan klinis berupa lesi dengan karakteristik area dari retinitis aktif disekitar sikatrik korioretinal yang tidak aktif dan hubungannya dengan hasil pemeriksaan laboratorium (pemeriksaan serologi). Pemeriksaan serologi yang dapat dilakukan adalah pemeriksaan menggunakan indirect fluorescent dan ELISA untuk mendeteksi antibodi T. gondii yang biasanya digunakan untuk mengkonfirmasi parasit. Walaupun pemeriksaan serologi dapat membantu diagnosis tetapi pemeriksaan ini tidak terlalu meyakinkan.
Pasien dengan toksoplasmosis okular selalu menunjukkan hasil positif untuk antigen IgG Toksoplasmosis begitu juga dengan pasien yang tidak menunjukkan keterlibatan ocular, karena hal tersebut, deteksi antigen spesifik IgG Toksoplasma sangat rendah nilainya dalam menegakkan diagnosis. ${ }^{18}$

Antibodi IgG masih terdapat dalam 2 minggu pertama setelah infeksi dan masih dapat terdeteksi selama kehidupan walaupun dalam jumlah yang sedikit dan dapat melewati pasenta. Pada beberapa pasien, deteksi antigen spesifik IgM Toksoplasma dapat diperoleh dari serum yang mengindikasikan infeksi yang baru didapat, dan levelnya meningkat pada fase akut dan masih dapat dideteksi kurang dari 1 tahun dan tidak dapat melewati plasenta. Jika data serologi membuktikan infeksi yang baru didapat, maka reaktivasi kondisi latent dapat disingkirkan. Adanya antibodi spesifik dapat mendukung diagnosis Toksoplasmic retinochoroiditis, dimana jika hasil pemeriksaan serologi yang negatif dapat menyingkirkan diagnosis. Penentuan antibodi $\lg \mathrm{A}$ dapat juga berguna untuk mendukung diagnosis toksoplasmosis kongenital pada bayi baru lahir, karena IgM biasanya diproduksi dalam beberapa minggu dan IgG mengindikasikan transfer pasif dari antibodi ibu selama dalam kandungan. ${ }^{19}$

Berdasarkan anamnesis, pemeriksaan fisik dan pemeriksaan serologi yang didapatkan dari keempat pasien, maka ditegakkan diagnosis chorioretinitis ec toksoplasmosis. Keempat pasien tersebut mendapatkan terapi yang sama, yaitu: Bactrim $F$ 2x960 mg (dewasa), Bactrim 2x480 mg (anak), ranitidin 2x150 mg dan prednison $1 \mathrm{mg} / \mathrm{kg}$ BB/hari. Sedangkan 1 pasien tidak diberikan terapi karena pasien tidak datang kembali untuk kontrol. Tujuan pemberian terapi pada toksoplasmosis adalah untuk memperpendek atau menghentikan replikasi organisme sehingga mempercepat terbentuknya sikatrik dan membatasi sikatrik chorioretinal dan progresifitas, mengurangi reaksi inflamasi dan meminimalkan komplikasi. ${ }^{20}$

Berbagai terapi dapat digunakan untuk toksoplasmosis okular dan tidak ada konsensus yang menetapkan terapi mana yang harus digunakan sebagai lini pertama karena tidak ada perbedaan yang 
signifikan pemberian terapi menggunakan pyrimethamine dan sulfadiazine, trimethoprim/ sulfamethoxazole, azithromycin dan clindamycin dan atovaquone. Beberapa obat-obatan yang dapat digunakan untuk terapi toksoplasmosis okular diantaranya: Pyrimethamine 75-100 mg loading yang diberikan selama 24 jam dan diikuti $25-50 \mathrm{mg}$ setiap hari selama 4-6 minggu. Sulfadiazine 2-4 gram loading dose diikuti dengan 1 gram diberikan 4 kali sehari selama 4-6 minggu. Prednison 40-60 mg sehari selama 2-6 minggu, pemberian prednison harus di tappering off sebelum penghentian pemberian pyrimethamine/sulfadiazine. Asam folat $5.0 \mathrm{mg}$ tablet atau $3.0 \mathrm{mg}$ diberikan secara intra vena 2-3 kali seminggu selama terapi pyrimethamine. ${ }^{20}$

Pada keempat pasien ini diberikan terapi menggunakan trimethoprim/sulfamethoxazole, karena obat ini merupakan modalitas terapi yang efektif, relatif aman untuk terapi toksoplasmosis ocular, harga yang murah dan efek samping yang sedikit. Kejadian efek samping yang pernah dilaporkan adalah gangguan gastrointestinal dan reaksi alergi kulit. Selain antimikroba juga digunakan prednison untuk mengurangi reaksi inflamasi dan digunakan terutama untuk lesi yang berada di makula. ${ }^{20}$

Penelitian yang dilakukan oleh Felix Fernandes (2012) dalam Reich (2015) menunjukkan pemberian trimethoprim/sulfamethoxazole setiap 2 hari dengan dosis $960 \mathrm{mg}$ selama 12 bulan terbukti 100\% menurunkan rekurensi retinochoroiditis Toksoplasma gondii. ${ }^{20}$

\section{SIMPULAN}

Terapi trimethoprim/sulfamethoxazole dapat digunakan untuk manajemen toksoplasmosis okular karena tidak ada perbedaan yang signifikan dari berbagai terapi sistemik yang ada. Prognosis pada pasien toksoplasmosis ocular tidak terlalu baik karena lesi yang berada di daerah makula.

\section{UCAPAN TERIMA KASIH}

Terima kasih kepada Ketua Program Studi IImu Kesehatan Mata Program Pendidikan Dokter Spesialis Fakultas Kedokteran Universitas Andalas dan Ketua
Bagian IImu Kesehatan Mata RSUP Dr. M. Djamil Padang yang telah membantu dalam penulisan laporan kasus ini.

\section{DAFTAR PUSTAKA}

1. Klintworth GK, Garner A. Ocular toxoplasmosis: Pathobiology of ocular disease. Edisi ke-3. New York: Informa. 2008. hlm.190-205.

2. Maenz M, Schluter D, Liesenfeld O, Schares G, Gross U, Pleyer U. Ocular toxoplasmosis past, present and new aspect of an old disease. Progress in Retinal and Eye Research. 2014; 39: 77-106.

3. Park HY, Nam WH. Clinical features and treatment of ocular toxoplasmosis. Korean Journal Parasitology. 2013;51:393-9.

4. Cantor BL, Rapuano JC, Cioffi AG. Toxoplasmic chorioretinitis: basic and clinical science course retina and vitreous. American Academy of Ophthalmology; 2014.hlm.206-9.

5. Garweg GJ, Mijnes FDJ, Montoya GJ. Diagnostic approach to ocular toxoplasmosis: Ocular Immunology and Inflammation. 2011; 19: 255-61

6. Cantor BL, Rapuano JC, Cioffi AG. Toxoplasmis. Basic and Clinical Science Course Intraocular Inflammation and Uveitis. American Academy of Ophthalmology; 2014. hlm. 226-34.

7. Mendelcorn. DE. Infectious causes of posterior uveitis. Canadian Journal Ophthalmology. 2013; 48:31-9.

8. Saffra N, Seidman CJ, Weiss LM. Ocular toxoplasmosis: controversies in primary and secondary prevention. National Institutes Of Health. 2013;4:1-11.

9. Kaye A. Toxoplasmosis: diagnosis, treatment and prevention in congenitally exposed infant. Journal of Pediatric Health. 2010;25:355-64.

10. Butler NJ. Ocular toksoplasmosis II: clinical features, pathology and management. Clinical Experiment Ophthalmology. 2011; 41:95-108.

11. Bollani L, Strocchio L, Stronati M. Congenital toxoplasmosis. Early Human Development. 2013; 2013:S70-S1 
12. Yazici A, Ozdal CP, Taskintuna I, Kavuncu S, Koklu G. Trimethoprim/sulfamethoxazole and azithromycin combination therapy for ocular toxoplasmosis. Ocular Immunology \& Inflammation. 2010;17:289-91.

13. Kartasasmita A, Muntur WP, Enus S, Iskandar E. Rapid resolution of toxoplasma chorioretinitis treatment using quadruple therapy. Clinical Ophthalmology. 2017;11:2133-7.

14. Kim JS, Scott UI, Brown CG, Brown MM, Ho CA, Michael. Interventions for toxoplasma retinochoroiditis. Ophthalmology. 2013;120:371-8.

15. Grigg EM, Dubey PJ, Nussenblatt BR. Ocular toxoplasmosis: lesson from Brazil. American Journal of Ophthalmology. 2015; 159:999-1001.

16. Nassaji M, Daraie G, Ghorbani R. Clinical feature and treatment outcome of active ocular toxoplasmosis in immunocompetent patients. Asian Pacific Journal of Tropical Medicine. 2010;7:571-3.

17. Crosier G. Update on the treatment of ocular txoplasmosis. International Journal of Medical Science. 2009;6:140-2.

18. Harrel M, Carvounis P. Current treatment of toxoplasma retinochoroiditis: an evidence based review. Journal of Ophthalmology. 2014; 2014:1-7.

19. Schallhorn JM, Gonzales J. Ocular toxoplasmosis: the treatment dilemma. Jounal of American Association Pediatric Ophthalmology and Strabismus. 2013;17:454-5.

20. Reich M. Time patterns of recurrences and factors predisposing for a higher risk of recurrence of ocular toxoplasmosis. Retina, The Journal of Retinal and Vitreous Diseases. 2015;35:809-19. 